\title{
Nutrition, quality of life and palliative care: integrative review
}

\author{
Nutrição, qualidade de vida e cuidados paliativos: uma revisão integrativa \\ Suelyne Rodrigues de Morais ${ }^{1}$, Alane Nogueira Bezerra², Natália Sales de Carvalho ${ }^{3}$, Ana Carolina Cavalcante Viana ${ }^{1}$
}

DOI 10.5935/1806-0013.20160031

\section{ABSTRACT}

BACKGROUND AND OBJECTIVES: Adequate nutritional intervention promotes wellbeing, symptoms control and improved quality of life for patients and their families. This study aimed at evaluating whether nutrition may or may not improve quality of life of patients under palliative care.

CONTENTS: This is an integrative review using Pubmed, Scielo and Medline databases. Guiding question was: "Is nutritional therapy able to improve quality of life of patients under palliative care?" Six articles met pre-established inclusion criteria. Nutritionists were professionals most orienting nutritional therapy, in addition to explaining nutritional strategies to minimize dietrelated discomforts. Adequate therapy should respect dietary and cultural preferences, thus assuring better quality of life.

CONCLUSION: Nutritional approach during palliative care should respect patients and their families' decisions and bioethics principles. Nutritional interventions should give more importance to counseling and support, instead of focusing just on matching nutritional needs. Nutritionists should orient patients and their families about nutritional therapy, in addition to giving further explanations to prolong survival, decrease weight loss and improve quality of life.

Keywords: Bioethics, Nutritional therapy, Nutritionist, Palliative care, Quality of life.

\section{RESUMO}

JUSTIFICATIVA E OBJETIVOS: A intervenção nutricional adequada promove bem-estar, controle de sintomas e melhora da qualidade de vida dos pacientes e de seus familiares. $\mathrm{O}$ objetivo deste estudo foi verificar se a nutrição pode ou não melhorar a qualidade de vida do paciente em cuidados paliativos.

CONTEÚDO: Trata-se de uma revisão integrativa, utilizando

1. Hospital Universitário Walter Cantídio, Residência em Assistência em Transplantes, Fortaleza, CE, Brasil.

2. Hospital Universitário Walter Cantídio, Residência em Assistência em Diabetes. Fortaleza, CE, Brasil.

3. Universidade de Fortaleza. Fortaleza, CE, Brasil.

Submitted in August 20, 2015.

Accepted for publication in April 11, 2016.

Conflict of interests: none - Sponsoring sources: none.

Correspondence to:

Suelyne Rodrigues de Morais

Rua Capitáo Francisco Pedro, 1290 - Rodolfo Teófilo

60430-370 Fortaleza, CE, Brasil.

E-mail: suelyne_rodrigues@hotmail.com

(C) Sociedade Brasileira para o Estudo da Dor as bases de dados Pubmed, Scielo e Medline. A pergunta norteadora foi "A terapia nutricional é capaz de melhorar a qualidade de vida dos pacientes em cuidados paliativos?". Seis artigos se enquadravam nos critérios de inclusão pré-estabelecidos. $\mathrm{O}$ nutricionista foi o profissional que mais orientou sobre a terapia nutricional em uso, além de fornecer esclarecimentos sobre estratégias nutricionais para redução de desconfortos ligados à alimentação. A terapia adequada deve respeitar as preferências alimentares e culturais, garantindo, assim, melhor qualidade de vida.

CONCLUSÁO: A conduta nutricional em cuidados paliativos deve respeitar as decisóes do paciente e de sua família e os princípios bioéticos. As intervençôes nutricionais devem dar maior importância à prestação de aconselhamento e de apoio, ao invés de centrar apenas na adequação das necessidades nutricionais. $\mathrm{O}$ nutricionista deve orientar o paciente e sua família sobre a terapia nutricional em uso, além de fornecer orientaçôes e esclarecimentos, a fim de prolongar a sobrevida, reduzir a perda de peso e melhorar a qualidade de vida.

Descritores: Bioética, Cuidados paliativos, Nutricionista, Qualidade de vida, Terapia nutricional.

\section{INTRODUCTION}

The World Health Organization (WHO) has published in 1990 a definition of palliative care (PC) and this concept was updated in 2002 being internationally accepted: "Palliative care is an approach that improves the quality of life of patients and their families facing the problem associated with life-threatening illness, through the prevention and relief of suffering by means of early identification and impeccable assessment and treatment of pain and other problems, physical, psychosocial and spiritual". In palliative care, when cure is no longer possible, therapeutic strategy should be based on maintaining patients' autonomy preserving the most from their normal lives or helping people enjoy their vitality within their limits ${ }^{2}$. Observing that quality of life (QL) is individuals' perception of their position in life, in the context of the culture and value system within they live, and also considering objectives, expectations, patterns and interests, one may state that PC aims at reaching the best possible QL for patients and their families, without delaying or hastening death, which should be respected for being a constitutive element of the natural process of life ${ }^{3}$. So, PC should be an alternative for the assistance to patients without therapeutic possibilities of cure to be human, fair and beneficial ${ }^{2}$.

A multiprofessional attention helping pain control and management, but also social, psychological and spiritual aspects, may decrease patients' suffering and promote $\mathrm{QL}^{2}$. The most 
important thing for PC is to preserve patients' dignity and to provide comfort and wellbeing, which may be reached by means of minor and simple actions, such as basic hygiene, adequate attention, comfortable furniture and $\operatorname{diet}^{4}$. It is critical to use resources preventing nutritional and gastrointestinal manifestations, such as anorexia, nausea, vomiting, wasting, malnutrition and dehydration, in addition to relieving their repercussions and extensions, if already installed ${ }^{5}$.

PC should respect patients' desires and should supply the most possible comfort by means of indicated therapies to minimize distress, but there are controversies whether food could contribute to this process. In general, these patients have some nutritional impairment, but not always this recovery is reached by means of nutritional therapy. Nutritional, caloric, protein and water requirements should be established according to patients' acceptance, tolerance and symptoms, aiming at promoting comfort and better QL and not only assuring adequate nutrients ingestion, preventing in some cases unnecessary invasive nutritional interventions, such as introduction of enteral nutritional therapy (ENT) or parenteral nutritional therapy $(\mathrm{PNT})^{6}$.

This study aimed at observing whether nutritional orientation may improve QL of PC patients by means, considering that an adequate nutritional intervention promotes wellbeing, symptoms control and better QL of patients and their families.

\section{CONTENTS}

This is an integrative review consisting of six stages, where the first stage is to decide the hypothesis or question of the study.
Then, a sample of scientific articles to be reviewed is selected, followed by categorization and evaluation of such studies. Interpretation of results and presentation of the review or of the summary of the knowledge are the last steps of this process ${ }^{7}$. Articles were selected using Pubmed, Scielo and Medline databases, by means of the following keywords: bioethics (bioética); palliative care (cuidados paliativos); nutrition (nutrição); nutritionist (nutricionista).

The following question was developed to guide the study: "Is nutritional therapy able to improve quality of life of patients under palliative care?", complying with the following inclusion criteria: mentioning PC patients' nutrition, being indexed in databases, being published in Portuguese or English between 2005 and 2015 and being available in full. Exclusion criteria were all articles of restricted access and literature reviews.

Articles were selected by reading titles and respective abstracts aiming at checking the matching of the study to the guiding question. At the end of the search, 16 studies were found, however 10 studies were excluded because nutritionist was mentioned by there were no results on nutritional guidance. So, only six have met pre-established inclusion criteria, of which four are quantitative studies and two are qualitative studies. For data extraction identification, characteristics of study methods, evaluation of methodological rigor, studied interventions and results were investigated. Data and discussion were presented in descriptive form, making possible the application of this review to nutrition practice in PC. Included articles are shown in table 1.

Table 1. Information on articles included in the integrative review according to the guiding question. Fortaleza, 2015

\begin{tabular}{|c|c|c|c|c|}
\hline Authors & Objectives & Methods & Results & $\begin{array}{l}\text { Is nutritional therapy able to im- } \\
\text { prove quality of life of patients } \\
\text { under palliative care? }\end{array}$ \\
\hline $\begin{array}{l}\text { Schirmer, } \\
\text { Ferrari \& } \\
\text { Trindade }^{8}\end{array}$ & $\begin{array}{l}\text { Evaluate the evolution of } \\
\text { oral mucositis in cancer } \\
\text { patients assisted by the } \\
\text { PC service, after medi- } \\
\text { cal and nutritional inter- } \\
\text { vention and guidance, } \\
\text { in addition to evaluating } \\
\text { how mucositis severity } \\
\text { interferes with patients' } \\
\text { food ingestion. }\end{array}$ & $\begin{array}{l}\text { Qualitative prospecti- } \\
\text { ve study using inter- } \\
\text { views and previously } \\
\text { structured question- } \\
\text { naire. }\end{array}$ & $\begin{array}{l}\text { Before intervention, mucositis grade I was } \\
\text { present in more than half the patients and } \\
\text { almost half of them ingested solid food. } \\
\text { Few individuals had mucositis grade IV } \\
\text { where all ingested liquid food. After inter- } \\
\text { vention, more than half the patients had } \\
\text { no mucositis and no restrictions to diet } \\
\text { consistency. Oral complaints, such as xe- } \\
\text { rostomia dysgeusia, appetite loss, anore- } \\
\text { xia and candidiasis were decreased. }\end{array}$ & $\begin{array}{l}\text { Nutritional guidance, such as } \\
\text { mouth washing with chamomile } \\
\text { tea, avoiding very acid, dry, hard } \\
\text { or spicy food, restrict salt, avoid } \\
\text { very hot food or preparations } \\
\text { may help improving mucositis, } \\
\text { thus assuring better QL. }\end{array}$ \\
\hline $\begin{array}{l}\text { Loyolla, } \\
\text { Pessini, } \\
\text { Bottoni, et } \\
\text { al. }{ }^{9}\end{array}$ & $\begin{array}{l}\text { Analyze, from bioethics } \\
\text { point of view, the use } \\
\text { of nutritional therapy for } \\
\text { cancer patients under } \\
\text { PC, observing vision and } \\
\text { participation of patients } \\
\text { and their families in the } \\
\text { decision to use such } \\
\text { therapy }\end{array}$ & $\begin{array}{l}\text { Qualitative study with } \\
\text { semistructured ques- } \\
\text { tionnaire. }\end{array}$ & $\begin{array}{l}\text { Most patients and caregivers were in- } \\
\text { formed about indicated ENT by the nu- } \\
\text { tritionist. When asked about what is and } \\
\text { what is the purpose of TNE, most have } \\
\text { answered that it served to fortify and feed } \\
\text { patients. With regard to the choice by pa- } \\
\text { tients or caregivers to start or not TNE, } \\
\text { answer was yes for many, but some were } \\
\text { in doubt and thought that this should be } \\
\text { a physician's decision. As to ENT being a } \\
\text { basic care that should always be provided, } \\
\text { answers have varied from replacement by } \\
\text { other if not bringing benefits or cannot be } \\
\text { withdrawn because it is patient's right. }\end{array}$ & $\begin{array}{l}\text { ENT is considered a basic care } \\
\text { by patients and/or caregivers } \\
\text { and is patient's right, which shall } \\
\text { be replaced but never with- } \\
\text { drawn if not bringing benefit to } \\
\text { patients. Although nutritionist } \\
\text { was the professional more ex- } \\
\text { plaining about ENT, patients and } \\
\text { caregivers feel they are unable } \\
\text { to decide about using ENT. }\end{array}$ \\
\hline
\end{tabular}


Table 1. Information on articles included in the integrative review according to the guiding question. Fortaleza, 2015 - continuation

\begin{tabular}{|c|c|c|c|c|}
\hline Authors & Objectives & Methods & Results & $\begin{array}{l}\text { Is nutritional therapy able to im- } \\
\text { prove quality of life of patients } \\
\text { under palliative care? }\end{array}$ \\
\hline
\end{tabular}

\begin{tabular}{ll}
\hline Silva, & $\begin{array}{l}\text { Analyze, by means of } \\
\text { Lopeviously validated }\end{array}$ \\
Trindade, & $\begin{array}{l}\text { questionnaire, how nu- } \\
\text { et al. } .^{10}\end{array}$ \\
& $\begin{array}{l}\text { tritional intervention and } \\
\text { symptoms control have } \\
\text { interfered with QL of can- } \\
\text { cer patients. }\end{array}$
\end{tabular}

Orrevall, Tishelman, nal risk status and the Permert, et use of nutritional therapy al. ${ }^{11} \quad$ among cancer patients enrolled in home PC services.

Muir \& Linklater $^{12}$

Explore the meaning of food, food ingestion and body weight of PC patients, investigating the impact of such changes on such patients, in addition to determining whether nutritional recommendations were followed ${ }^{13}$.

Hasenberg, Evaluate the effect of paEssenbreis, renteral nutrition suppleHerold, et mentation on body comal. ${ }^{13}$ position, QL, secondary effects associated to chemotherapy and survival in patients with advanced colorectal cancer.
Quantitative pros- Most patients were under oral diet and pective study. Tools: three previously structured questionnaires on QL, socioeconomic aspects and food questionnaire ${ }^{11}$.

Quantitative study using phone interview and a questionnaire were classified as lacking more intensive care. After medical and nutritional interventions and discussion of cases, the use of food supplements and gastrointestinal symptoms have decreased and appetite was improved, in addition to better QL of patients.

Most studied patients were diagnosed as at nutritional risk. As to nutritional therapy, most used common oral nutritional supplements, while the minority used artificial nutrition, especially PNT. Common oral supplements were related to low BMI and severe weight loss.

Qualitative

study A recurrent theme was change and uncerusing semistructured tainty. Four major areas subject to variainterviews. tion were: disease status, symptoms, oral ingestion and weight. Each change could control or be controlled by patients. When patients were unable to control they accepted the change, be it voluntarily or not $^{13}$.

Quantitative retrospective randomized study.

Groups receiving parenteral supplementation or oral nutrition have improved gastrointestinal symptoms, resulting in signi-

Giving diet and therapy guidance contemplating dietary indication, diet consistency, possible associated comorbidities, respecting food and cultural preferences, minimizing food-related discomfort, thus assuring better QL.

Evaluate the nutritional risk of PC patients helps improving nutritional approach, however the use of nutritional therapy should consider life expectancy and patients' psychosocial aspects.

The article shows that nutritional guidance given to palliative care patients by means of standardized nutritional requirements may fail by not addressing the real meaning of nutritional care for such patients. So, nutritional interventions with these patients should give more importance to offering counseling and support instead of focusing on calculated nutritional requirements. ficantly increased appetite.

Nutritional therapy as oral or parenteral supplementation improves QL, prolongs survival and decreases weight loss.

\section{DISCUSSION}

Untreated mucositis may interfere with nutritional status and even interfere with the choice of anti-cancer therapy, in addition to impairing patients' $\mathrm{QL}^{14}$. According to Schirmer, Ferrari and Trindade ${ }^{8}$, nutritional therapy may prevent severe oral mucositis ${ }^{8}$. According to Boligon and Huth ${ }^{15}$, supplementation with $20 \mathrm{~g} /$ day glutamine for head and neck cancer patients under anti-cancer therapy has helped the maintenance of nutritional status and has prevented mucositis, especially grades III and IV. In case of moderate to severe mucositis, enteral nutrition with nasogastric/nasoenteric probe, or even parenteral nutrition, should be indicated in cases of weight loss above $5 \%$. So, medical and nutritional care is needed to contribute to anti-cancer therapy maintenance, as well as to patients' weight maintenance and hydration ${ }^{16}$.

Multiprofessional action is mandatory for the efficient management of PC patients, helping improving complications, $\mathrm{QL}$ and their autonomy' ${ }^{9}$. This should be achieved by means of better interaction among professionals, considering the individualized choice of pharmacological and dietary therapy, in addition to minimizing drug-related adverse effects ${ }^{10}$.

Loyolla et al. ${ }^{9}$ have observed that patients and caregivers were informed about nutritional therapy and knew how to define its function and importance. However, it was observed that information given by professionals was not enough or was not clear for most patients and caregivers. This transfers ENT responsibility to the physician aiming at assuring patients' benefit. In addition, physician, patient and caregiver relationship still follows the old paternalist pattern, an asymmetric relationship where the only decision-maker on therapy is the physician.

According to Cardoso et al. ${ }^{17}$ the multiprofessional team identifies weaknesses and challenges, such as the need to qualify communication and team work. The nutritionist is one professional responsible for providing nutritional guidance to patients and their families. So, nutritionist must have communication skills, being this as important as technical knowledge regarding nu- 
tritional requirements. Dietary prescription should, above all, offer pleasure and comfort to patients, in addition to respecting their will ${ }^{2}$. So, it is clear that patients' autonomy, while being conscious and able to decide, should be respected, otherwise, family should determine what is best ${ }^{9}$.

Silva et al. ${ }^{10}$ have shown that nutritional and medical interventions have indirectly reflected on socialization and have allowed patients' participation in meals together with relatives and friends, in addition to implying comfort and self-care. This has shown that nutritional aspects are not only those related to nutritional status, but also those related to family relations, pleasure, wellbeing and autonomy. Seredynskyj et al. ${ }^{18}$ have observed that autonomy should be preserved for the maintenance of better patients' health status. In addition, simultaneous medical and nutritional intervention has also resulted in improved symptoms such as appetite loss, dysgeusia, oral candidiasis, mucositis, nausea and constipation, similarly to Durval et al. ${ }^{19}$ findings, who have shown improved wasting, thus contributing to better QL. When strategies to favor food ingestion are obtained, results portray patients' clinical and social approach, improving their life condition ${ }^{10}$.

Orrevall et al. ${ }^{11}$ have observed that more than two thirds of patients were at nutritional risk, which was associated to precancer low body mass index (BMI). However, an association between pre-cancer BMI indicating overweight and nutritional risk was also found, being indicated that nutritional problems may not be easily identified without nutritional tracking, even after severe weight loss. This study has shown the need for a structured approach to early identify and evaluate cancer patients on nutritional risk. However, any evaluation tool which may generate physical or emotional discomfort should not be used in this stage.

Incurable cancer is associated to high prevalence of nutritional problems and weight loss, leading to physical and psychological impairment. Nutritional implications should be identified and treated as early as possible during disease progression, however, in later stages, nutritional therapy is still controversial ${ }^{20}$.

Nutritional therapy is part of integral oncological support and may significantly contribute to improve $\mathrm{QL}^{21}$. However, ENT or PNT should only be started in individuals with better life expectance and/or if there are psychosocial aspects favoring such process, to assure better life condition to patients, sparing those with no indication from unnecessary interventions ${ }^{22}$.

Muir and Linklater ${ }^{12}$ have observed the testimony of patients, allowing a broad understanding of their concerns. For them, food goes beyond nutritional objectives; it is reflected on motivation, control along disease progression, care and compassion expressions, and death acceptance. Health worsening may be often identified by not being able to eat ${ }^{22}$.

With regard to meaning, foods are physical substances necessary as energy source to feed the body and continue to fight against disease, which is source of frustration and anxiety, in addition to showing the sensation of patients' care and inter- est. Changes in food ingestion have followed the trend of decline, characterized by decreased appetite, oral ingestion and weight loss. Decreased consumption has induced physical and psychological changes in such patients. As to weight, loss was fearsome and stressing because death process was coming close. So, most of them have felt that weight monitoring could be noxious or even useless ${ }^{12}$.

Malnutrition is mentioned by studied patients not only as physical malnutrition, but also as psychological and sociological malnutrition. Weight loss may be identified by many as symbol of disease progression, loss of control of their own body and physical and emotional weakness, and may also represent the proximity of death. Many times it is related to weakness, fatigue and decreased $\mathrm{QL}^{23}$. Nutritional care strategies with holistic approach should be developed to meet the broad meanings that food or eating may have, because already defined protocols and standards may not meet individual requirements and even overload patients with unfeasible targets, such as weight gain and adequate nutritional ingestion ${ }^{12}$. So, sensitivity and creativity will make the difference during nutritional evaluation and guidance ${ }^{22}$. Aiming at improving $\mathrm{QL}$, the real meaning of PC nutritional care should be addressed, especially by means of assuring patients' counseling and support ${ }^{12}$.

Hasenberg et al. ${ }^{13}$ have observed that early nutritional therapy may maintain body composition, improve life condition and even prolong survival of cancer patients under $\mathrm{PC}^{13}$. It is necessary to stress that unintentional weight loss and changes in body composition are related to unfavorable clinical evolution, psychological, socioeconomic and QL impairment ${ }^{21}$. This article has observed the effects of parenteral and oral nutrition supplementation. Group receiving PNT and oral nutrition have stabilized albumin levels, in addition to improving gastrointestinal symptoms related to chemotherapy, thus improving QL. Patients receiving oral supplementation have reported improved symptoms, such as early satiation, constipation, nausea, vomiting, abdominal pain and diarrhea, resulting in significant appetite improvement in this group ${ }^{13}$. So, nutritional intervention has positively impacted clinical and social aspects, improving individuals' life condition.

Anti-cancer therapies may produce additional symptoms, negatively affecting nutritional status, depending on treatment type and duration, dose and individual patients' response $^{21}$. Nutritional therapy helps decreasing treatment-related symptoms and disease evolution, as well as weight loss, prolonging survival and improving $\mathrm{QL}^{13}$.

In light of the above, dietary approach should, above all, offer pleasure and comfort, respecting patients and their families' autonomy. So, together with other therapeutic measures, it may contribute to promote QL of patients without clinical possibilities of cure.

\section{CONCLUSION}

Nutritional approach in PC should respect patients and their families' decisions, as well as bioethics principles: autonomy, 
beneficence, non malfeasance and justice. Nutritional therapy may prolong survival, decrease weight loss and improve QL of PC patients, by means of decreasing adverse effects of treatments and/or diseases. Considering the importance of this article, there is need for further nutrition studies involving PC patients, not only in the oncologic area, but also in all different situations involving this theme.

\section{REFERENCES}

1. World Health Organization. National cancer control programmes: policies and managerial guidelines. $2^{\text {nd }}$ ed. Genebra. 2002.

2. Corrêa PH, Shibuya E. Administraçáo da terapia nutricional em cuidados paliativos. Rev Bras Cancerol. 2007;53(3):317-23.

3. World Health Organization. WHO definitions of palliative care. 2015. Acesso em 24 de julho de 2015. Disponível em: < http://www.who.int/cancer/palliative/definition/en $>$.

4. Nordon DG, Moreno MS, Figueiredo MT, Figueiredo MG. Palliative care in alzheimer's disease. Rev Fac Ciênc Méd Sorocaba. 2010;12(2):1-3.

5. Sociedad Espańola de Cuidados Paliativos. Guia de cuidados paliativos. 2008. Acesso em 24 de julho de 2015. Disponível em: <http://www.secpal.com/guiacp/index.php>.

6. Instituto Nacional de Câncer (Brasil). Consenso Nacional de Nutriçấo Oncológica. Rio de Janeiro: INCA; 2009. Disponível em: <http://www.asbran.org.br/arquivos/ consenso_nutricao_oncologia.pdf>

7. Beyea SC, Nicoll LH. Writing an integrative review. AORN J. 1998;67(4):877-80.

8. Schirmer EM, Ferrari A, Trindade LC. Evolução da mucosite oral após intervençăo nutricional em pacientes oncológicos no serviço de cuidados paliativos. Rev Dor. 2012;13(2):141-6

9. Loyolla VC, Pessini L, Bottoni A, Serrano, SC, Teodoro AL, Bottoni A. Terapia nutricional enteral em pacientes oncológicos sob cuidados paliativos: uma análise da bioética. Saúde, Ética \& Justiça. 2011;16(1):47-59.

10. Silva PB, Lopes M, Trindade LC, Yamanouchi CN. Controle dos sintomas e interven- ção nutricional. Fatores que interferem na qualidade de vida de pacientes oncológicos em cuidados paliativos. Rev Dor. 2010;11(4):282-8.

11. Orrevall Y, Tishelman C, Permert J, Cederholm T. Nutritional support and risk status among cancer patients in palliative home care services. Support Care Cancer. 2009;17(2):153-61.

12. Muir CI, Linklater GT. A qualitative analysis of the nutritional requirements of palliative care patients. J Hum Nutr Diet. 2011;24(5):470-8.

13. Hasenberg T, Essenbreis M, Herold A, Post S, Shang E. Early supplementation of parenteral nutrition is capable of improving quality of life, chemotherapy-related toxicity and body composition in patients with advanced colorectal carcinoma undergoing palliative treatment: results from a prospective, randomized clinical trial. Colorectal Dis. 2010;12(10):e190-e9.

14. Wong PC, Dodd MJ, Miaskowski C, Paul SM, Bank KA, Shiba GH, et al. Mucositis pain induced by radiation therapy: prevalence, severity, and use of self-care behaviors. J Pain Symptom Manage. 2006;32(1):27-37.

15. Boligon CS, Huth A. O impacto do uso de glutamina em pacientes com tumores de cabeça e pescoço em tratamento radioterápico e quimioterápico. Rev Bras Cancerol. 2011;57(1):31-8.

16. Stone R, Fliedner MC, Smiet AC. Management of oral mucositis in patients with cancer. Eur J Oncol Nurs. 2005;9( Suppl 1):S24-32.

17. Cardoso DH, Muniz RM, Schwartz E, Arrieira IC. Cuidados paliativos na assistência hospitalar: a vivência de uma equipe multiprofissional. Texto Contexto Enferm. 2013;22(4):1134-41.

18. Seredynskyj FL, Rodrigues RA, Diniz MA, Fhon JR. Percepçấo do autocuidado de idosos em tratamento paliativo. Rev Eletr Enf. 2014;16(2):286-96.

19. Durval PA, Vargas BL, Fripp JC, Arrieira IC, Lazzeri B, Destri K, Assunção MC. Caquexia em pacientes oncológicos internados em um programa de internaçấo domiciliar interdisciplinar. Rev Bras Cancerol. 2010;56(2):207-12.

20. Bozzetti, F. Home total parenteral nutrition in incurable cancer patients: a therapy, a basic humane care or something in between? Clin Nutr. 2003;22(2):109-11.

21. Marín Caro MM, Laviano A, Pichard C, Gómez Candela C. Relación entre la in tervención nutricional y la calidad de vida en el paciente con cáncer. Nutr Hosp. 2007;22(3):337-50.

22. Benarroz MD, Faillace GB, Barbosa LA. Bioética e nutriçāo em cuidados paliativos oncológicos em adultos. Cad Saúde Pública. 2009;25(9):1875-82.

23. Shaw C, Eldridge L. Nutritional considerations for the palliative care patient. Int J Palliat Nurs. 2015;21(1):7-15. 